\title{
Novel findings from the Asian Lymphoma Study Group: focus on T and NK-cell lymphomas
}

\author{
Jason Yongsheng Chan ${ }^{1,2,4}$. Soon Thye Lim ${ }^{1,3,4}$
}

Received: 4 December 2017 / Revised: 16 January 2018 / Accepted: 22 January 2018 / Published online: 29 January 2018

(c) The Japanese Society of Hematology 2018

\begin{abstract}
$\mathrm{T}$ and NK-cell lymphomas are aggressive neoplasms with a unique epidemiological distribution, demonstrating higher prevalence in Asian countries compared to the West. Through the efforts of international collaboration, significant progress has been made especially on the biological understanding and clinical management of rare lymphoma subtypes including NK/T-cell lymphomas and monomorphic epitheliotropic intestinal T-cell lymphoma. In this review, we summarize the current status of lymphoma research conducted by the Asian Lymphoma Study Group and highlight key updates on the advancement of $\mathrm{T}$ and NK-cell lymphoma research.
\end{abstract}

Keywords JAK-STAT pathway $\cdot$ NK/T-cell lymphoma $\cdot$ Enteropathy-associated T-cell lymphoma $\cdot$ Epstein-Barr virus

\section{Abbreviations}

NKTCL NK/T-cell lymphoma

MEITL Monomorphic epitheliotropic intestinal T-cell lymphoma

ALSG Asian Lymphoma Study Group

ICGC International Cancer Genomic Consortium

\section{Introduction}

The epidemiology of non-Hodgkin lymphoma exhibits a unique geographic diversity, with a high prevalence of T-cell and NK/T-cell lymphomas in Asian countries compared to the West $[1,2]$. Over the past decade, significant progress has been made in the clinical management of nonHodgkin lymphoma in Asia. On the research front, the Asian

Soon Thye Lim

lim.soon.thye@singhealth.com.sg

1 Division of Medical Oncology, National Cancer Centre Singapore, Singapore, Singapore

2 Cancer Science Institute of Singapore, National University of Singapore, Singapore, Singapore

3 Office of Education, Duke-NUS Medical School, Singapore, Singapore

4 SingHealth Duke-NUS Blood Cancer Centre, Singapore, Singapore
Lymphoma Study Group (ALSG) brings together centers across East Asia to collaborate on studies on Asia-centric lymphoma, with participating members from Japan, South Korea, China, Taiwan, Singapore, Malaysia, Indonesia and Thailand. To date, the ALSG has published several important research findings across different lymphoma subtypes, including landmark discoveries on NK/T-cell lymphomas (NKTCL) and monomorphic epitheliotropic intestinal T-cell lymphoma (MEITL) (Tables 1, 2). In addition, the Singapore Lymphoma Study Group has been leading the whole genome sequencing of $\mathrm{T}$ and NK-cell lymphomas in the International Cancer Genomic Consortium (ICGC), illuminating major pathways and fundamental biological mechanisms underlying these diseases. In this review, we summarize the current status of lymphoma studies conducted by the ALSG and highlight key updates on the progress of $\mathrm{T}$ and NK-cell lymphoma research.

\section{Extranodal NK/T-cell lymphoma}

\section{Introduction and clinical features}

NKTCL is an aggressive Epstein-Barr virus (EBV)-associated hematological malignancy, with a predilection for extranodal involvement. Over the past years, the ALSG has taken a keen interest in understanding the molecular and clinical pathobiology of NKTCL. Epidemiologically, 
Table 1 Key publications on NKTCL from Asia (2009-2017)

Year of publication
Consensus guidelines and selected clinical series
2009

Consensus guidelines and selected clinical series

First multicentre consensus statement and resource-stratified guidelines on the optimal approach to diagnosis, staging, follow-up, and treatment of T and NKcell neoplasms in Asia

Retrospective series of patients with gastrointestinal NKTCL demonstrating poor median overall survival of 7.8 months despite active management with chemotherapy and surgery

Retrospective series of patients with primary cutaneous nasal-type NKTCL and EBV-negative CD56-positive PTCL from Asia demonstrating poor 5-year overall survival rates of $25 \%$

Treatment developments in localized NKTCL

Phase II study of concurrent chemoradiation using weekly cisplatin followed by VIPD (etoposide, ifosfamide, cisplatin, dexamethasone) in newly diagnosed localized NKTCL achieved a complete response rate of $80 \%$ and 3-year overall survival of $86 \%$

Phase II study of concurrent chemoradiation using the DeVIC regimen (dexamethasone, etoposide, ifosfamide, carboplatin) in newly diagnosed localized NKTCL reported a complete response rate of $77 \%$ and 5-year overall survival of $70 \%$

Retrospective analysis on patients with localized NKTCL demonstrating comparable outcomes with either concurrent or sequential chemoradiation, achieving a 5 -year overall survival of over $70 \%$

Treatment developments in advanced NKTCL

Prognostic models

Molecular pathogenesis

2012

2015

Initial phase II study on the SMILE regimen on patients with newly diagnosed or relapsed/refractory NKTCL, reporting an overall response rate of $79 \%$ after 2 cycles, with an updated 5-year overall survival of $47 \%$

Prospective confirmatory study of the SMILE regimen on patients with newly diagnosed and relapsed/refractory NKTCL, reporting an overall response rate of $81 \%$ and 5-year overall survival of $50 \%$

Retrospective series showing that allogeneic transplant in NKTCL achieved a 5 -year overall survival of $57 \%$ and 5-year event-free survival of $51 \%$, and that the use of the SMILE regimen pre-transplant was the most important prognostic indicator of superior survival outcomes

Retrospective series demonstrating that upfront autologous transplant achieved a 3 -year overall survival of $60 \%$ and 3-year progression-free survival of $52 \%$, and is a feasible and effective therapy in NKTCL patients who respond to initial primary therapy

Seven male patients with NKTCL who had failed L-asparaginase regimens and/or allogeneic transplant achieved treatment response to pembrolizumab according to various assessment criteria, with 5 patients achieving complete remission

Post-treatment circulating EBV DNA and PET-CT scoring independently associated with progression-free and overall survival after completion of primary treatment for NKTCL

Prognostic Index of Natural Killer lymphoma (PINK) model derived from a retrospective study of patients who had received non-anthracycline-based treatment. Four risk factors-age greater than 60 years, stage III or IV disease, distant lymph node involvement and non-nasal type strongly associated with poor survival outcomes

Whole exome sequencing identified JAK3 somatic mutations in 35\% of NKTCL cases, leading to constitutive activation of JAK-STAT signaling and increased cell growth

Whole exome sequencing identified recurrent somatic mutations in the RNA helicase gene $D D X 3 X$ in $20 \%$ of NKTCL cases, as well as tumor suppressors (TP53 and MGA), JAK-STAT-pathway molecules (STAT3 and STAT5B) and epigenetic modifiers (MLL2, ARID1A, EP300 and ASXL3) 
Table 1 (continued)

\begin{tabular}{ll}
\hline Year of publication & Study highlights \\
\hline 2016 & Genome-wide association study identified strong associations between $H L A-$ \\
& DPB1 single-nucleotide polymorphisms and susceptibility to NKTCL \\
\hline
\end{tabular}

NKTCL NK/T cell lymphoma, PTCL peripheral T-cell lymphoma

Table 2 Key publications on MEITL and other PTCL from Asia

\begin{tabular}{|c|c|c|}
\hline Year of publication & Study highlights & References \\
\hline \multicolumn{3}{|l|}{ MEITL } \\
\hline 2011 & $\begin{array}{l}\text { Clinicopathological characterization of MEITL demonstrating frequent } \gamma \delta \text { T-cell receptor expression and the } \\
\text { consistent presence of intraepithelial lymphocytosis }\end{array}$ & {$[38]$} \\
\hline 2011 & $\begin{array}{l}\text { Extensive nuclear expression of megakaryocyte-associated tyrosine kinase (MATK) and a CD8(+)CD56(+) } \\
\text { cytotoxic phenotype characterizes MEITL, distinguishing it from classical type I EATL }\end{array}$ & [39] \\
\hline 2012 & $\begin{array}{l}\text { Retrospective series on patients with MEITL demonstrating that the most common site of involvement } \\
(>80 \%) \text { was the small bowel, and that median overall survival was a dismal } 7 \text { months }\end{array}$ & {$[37]$} \\
\hline 2013 & $\begin{array}{l}\text { Molecular pathological study demonstrating that the majority of neoplastic cells in MEITL express CD8 } \alpha \alpha \\
\text { homodimers, and may reflect tumor progression from intraepithelial T-cell precursors }\end{array}$ & {$[40]$} \\
\hline 2016 & $\begin{array}{l}\text { Next generation sequencing identified prominent activation of JAK-STAT and G-protein coupled receptor } \\
\text { signaling pathways in MEITL. Mutations in STATSB, JAK3 and GNAI2 were detected, with the majority } \\
\text { occurring at known activating hotspots in key functional domains }\end{array}$ & {$[41]$} \\
\hline \multicolumn{3}{|l|}{ PTCL } \\
\hline 2014 & $\begin{array}{l}\text { Gene expression profiling identified unique signatures for major histological subgroups of PTCL, including } \\
\text { angioimmunoblastic T-cell lymphoma, anaplastic lymphoma kinase (ALK)-positive and ALK-negative } \\
\text { anaplastic large cell lymphoma, adult T-cell leukemia/lymphoma and NKTCL }\end{array}$ & {$[42]$} \\
\hline 2017 & $\begin{array}{l}\text { Gene expression profiling showed that compared with extranodal NKTCL, EBV-positive variant of PTCL, } \\
\text { non-otherwise specified ("primary nodal NKTCL") was distinctively characterized by upregulation of PD-L1 } \\
\text { and T-cell related genes, downregulation of CD56, as well as loss of 14q11.2 which correlated with loss of } \\
\text { TCR loci and T-cell origin }\end{array}$ & {$[43]$} \\
\hline
\end{tabular}

MEITL monomorphic epitheliotropic intestinal T-cell lymphoma, PTCL peripheral T-cell lymphoma, EATL enteropathy-associated T-cell lymphoma, $E B V$ Epstein-Barr virus

NKTCL demonstrates a geographic distribution that is more predominant in East Asia and South America compared to European and North American countries, with an incidence of around $3-10 \%$ and less than $1 \%$, respectively. In most cases, NKTCL presents as a destructive lesion in the nasal cavity and upper aerodigestive tract, although involvement of non-nasal regions have been described [3]. Extranasal NKTCL are characterized by more adverse clinical features, with worse overall survival outcomes in both early and late stage disease, compared to nasal subtypes [3]. In a retrospective analysis of 81 patients with gastrointestinal NKTCL from the ALSG, the majority involve the small intestine and more than $60 \%$ present with advanced disease. Despite active management with chemotherapy and surgery, median overall survival remains a dismal 7.8 months [4]. Another retrospective clinicopathologic study describing 60 patients with primary cutaneous nasal-type NKTCL and CD56-positive EBV-negative peripheral T-cell lymphoma (PTCL) from Asia demonstrated equally poor outcomes with a 5-year overall survival rate of only $25 \%$ [5].

\section{Clinical management updates}

The standard management of NKTCL is steadily evolving and current recommendations have been excellently summarized in recent reviews [6, 7]. Traditional treatment with anthracycline-containing regimens has been largely ineffective due to tumor expression of P-glycoprotein, and current treatment strategies for nasal-type NKTCL include mainly chemoradiation for localized disease [8-10] and L-asparaginase-based systemic chemotherapy for advanced cases [11, 12]. In localized NKTCL, the optimal sequencing of radiotherapy and chemotherapy remains a controversy. A recent retrospective analysis of a multicentre patient cohort showed that both concurrent and sequential chemoradiation resulted in similar outcomes, achieving an overall survival of over $70 \%$ after 5 years [13]. For advanced NKTCL, the SMILE (dexamethasone, methotrexate, ifosfamide, L-asparaginase, and etoposide) chemotherapy regimen is frequently adopted in Asia. The initial phase II study on 38 newly diagnosed or relapsed/refractory NKTCL reported an overall response 
rate of $79 \%$ after 2 cycles, with an updated 5-year overall survival of $47 \%$ [11, 14]. A subsequent study from the ALSG confirmed the efficacy outcomes, reporting an overall response rate of $81 \%$ and 5-year overall survival of $50 \%$ [12]. Despite these encouraging results compared to anthracycline-based regimens, the SMILE protocol is associated with unavoidable myelosuppression which can be severe despite G-CSF support, with grade 4 neutropenia occurring in most patients [11]. Supportive care strategies such as optimizing antibiotic prophylaxis and managing $\mathrm{L}$-asparaginase hypersensitivity reactions have been proposed to minimize the occurrence of treatment-induced toxicities [15].

In the contemporary management of NKTCL using L-asparaginase-based regimens, the role of high-dose chemotherapy with hematopoietic stem cell transplant (HSCT) in NKTCL is highly controversial. In the pre-SMILE era, a retrospective multicentre analysis including ten patients with NKTCL undergoing autologous or allogeneic hematopoietic stem cell transplant reported dismal outcomes with 5-year overall survival of $38 \%$ and progression-free survival of $37 \%$, with the lack of attaining complete or partial response at the time of transplant associated with worse outcome [16]. More recently, in a multicentre analysis of 18 patients from the ALSG, Tse and Kwong showed that allogeneic transplant achieved a 5-year overall survival of 57\% and 5-year event-free survival of 51\%, and that the use of the SMILE regimen pre-transplant was the most important prognostic indicator of superior survival outcomes. This study included patients with stage IV disease with bone marrow involvement at first complete remission or chemotherapy-sensitive relapsed/refractory disease. The majority of patients in this study received the SMILE regimen, and all except two patients were in complete remission at the time of transplant, probably accounting for the improved outcomes [17]. Similarly, upfront autologous HSCT has also been reported to be a feasible and effective therapy in NKTCL patients who respond to initial primary therapy [18]. Despite feasibility and efficacy data, given the comparable rates of efficacy outcomes achievable by SMILE or other L-asparaginase-based regimens alone, the exact utility of HSCT remains to be clarified in future studies.

\section{Novel therapies}

Salvage options post L-asparaginase regimens are currently lacking, though emerging data for novel therapeutic options are emerging. Recently, the ALSG reported remarkable response rates to the anti-programmed death 1 (PD1) antibody pembrolizumab in relapsed/refractory NKTCL. Seven male patients with NKTCL who had failed L-asparaginase regimens and/or allogeneic HSCT achieved treatment response according to various assessment criteria, with 5 patients achieving complete remission. Blockade of the PD1/
PDL1 axis in NKTCL certainly deserves further investigation in future studies [19]. We previously reported a single patient with relapsed disease who achieved complete response to B-GIFOX (bortezomib, gemcitabine, ifosfamide and oxaliplatin) [20]. The activity of gemcitabine-containing therapies in relapsed/refractory NKTCL was similarly observed in a retrospective cohort of 20 patients, with an overall response rate of $40 \%$ [21]. Alisertib is an inhibitor of Aurora A kinase, a centrosome-associated serine/threonine kinase which is overexpressed or amplified in a range of hematologic and non-hematologic malignancies [22]. A phase I study conducted on East Asian patients investigated the safety and tolerability of twice daily alisertib for 7 days in a 3 weekly cycle. Among 36 patients, which included 3 patients with NKTCL, the best response was a partial response in a patient with nasal-type NKTCL, achieving a duration of response of 5.6 months while on the established maximum tolerated dose of $30 \mathrm{mg}$ BID [23]. Other significant case reports in the setting of relapsed/refractory NKTCL include sustained responses to anti-CD30 therapy with brentuximab vedotin [24], and anti-CD38 antibody daratumumab [25].

\section{Prognostication and risk stratification}

Despite improved outcomes with the incorporation of L-asparaginase-based chemotherapy regimens as well as radiotherapy in the management of NKTCL, a substantial group of patients still experience treatment failure and disease relapse. Several prognostic models have been developed based on patients treated with anthracycline-based regimens $[3,26,27]$, undermining their relevance in the present era. Recently, a Prognostic Index of Natural Killer lymphoma (PINK) model was derived from a retrospective study of patients who had received non-anthracycline-based treatment in the International NK/T-Cell Lymphoma Project [28]. Four risk factors-age greater than 60 years, stage III or IV disease, distant lymph node involvement and non-nasal type were strongly associated with worse survival outcomes. Patients in the highest risk group had a 3-year overall survival of less than $30 \%$, highlighting profound inadequacies even with contemporary treatment approaches. Circulating EBV DNA in the peripheral blood has been correlated with tumor load, and has been associated with treatment response, toxicity, and survival in patients with NKTCL [29]. In corroboration with this result, the addition of detectable pre-treatment EBV DNA levels to the PINK model had similarly segregated patients into distinct prognostic groups [28]. The ALSG recently conducted a retrospective assessment of the prognostic relevance of post-treatment circulating EBV DNA as well as PET-CT scoring by the Deauville system, both of which were independently associated with progression-free and overall survival [30]. 


\section{Molecular pathobiology}

The molecular pathways implicated in the pathobiology of NKTCL are still poorly understood [31]. To understand the molecular epidemiology of this disease, we had previously conducted the first genome-wide association study on a large cohort of more than 500 patients with NKTCL. We identified strong associations between $H L A-D P B 1$ single-nucleotide polymorphisms and susceptibility to NKTCL, implicating altered antigen processing and presentation to CD4-positive $\mathrm{T}$ lymphocytes in the pathogenesis [32]. In recent years, next generation sequencing has led to a greater clarity of the genomic landscape of NKTCL, revealing recurrent somatic mutations such as TP53, JAK3, and DDX3X in NKTCL [33-35]. Using whole exome sequencing, we previously identified JAK3 somatic mutations in 35\% of NKTCL cases, leading to constitutive activation of JAK-STAT signaling and increased cell growth [34]. Similarly, another study by Lee et al. demonstrated frequent mutations (56\%) of STAT3 and other mutations in the JAK-STAT cascade in a cohort of 34 NKTCL tissue samples and cell lines. Interestingly, histone modification-related genes including BCOR and MLL2 were mutated in $38 \%$ of the samples, supporting a role for epigenetic dysregulation in NKTCL [35]. Most recently, our group investigated the interaction between JAK-STAT pathway signaling and the PD-L1 immune checkpoint protein. Using targeted sequencing of 188 genes associated with the JAK-STAT pathway in 109 NKTCL samples, we characterized a novel E616K mutant residing in the $\mathrm{SH} 2$ domain of STAT3. E616K not only conferred IL-3 independent growth to $\mathrm{Ba} / \mathrm{F} 3$ cells and increased STAT3 phosphorylation, $\mathrm{PD}-\mathrm{L} 1$ was also found to be overexpressed. Though preliminary, this suggests that the oncogenic JAK-STAT signals may promote NKTCL development by driving immune evasion [36]. Consequently, the combined inhibition of the PD-1/PD-L1 axis and JAK-STAT pathway may be a promising therapeutic approach for NKTCL.

\section{Monomorphic epitheliotropic intestinal T-cell lymphoma and other peripheral T-cell lymphoma}

MEITL, previously known as type II enteropathy-associated T-cell lymphoma (EATL), is a rare and aggressive nonHodgkin lymphoma arising from the intestinal tract. Whilst classical type I EATL is associated with celiac disease and is predominant in Western populations, type II EATL lacks this association and is more prevalent in Asia [37, 38]. Even so, a previous retrospective study by the ALSG identified only 38 patients in 4 institutions within a 19 -year period. The most common site of involvement $(>80 \%)$ was the small bowel, and the presenting features were perforation, pain and obstruction. Median overall survival was a dismal 7 months [37]. Histologically, MEITL is characterized by central sheets of monotonous neoplastic lymphocytes, a peripheral zone infiltrated by atypical intraepithelial lymphocytes (IELs), and distant mucosa with normal villous architecture and morphologically normal IELs. Distinct from classical type I EATL, extensive nuclear expression of megakaryocyte-associated tyrosine kinase (MATK) and a CD8(+)CD56(+) cytotoxic phenotype typifies the diagnosis of MEITL [39]. The majority of neoplastic cells express CD8 $\alpha \alpha$ homodimers, and may reflect tumor progression from intraepithelial T-cell precursors [40]. Recently, we demonstrated that JAK-STAT and G-protein coupled receptor signaling pathways are prominently activated in MEITL [41]. Mutations in STAT5B (63\%), JAK3 (35\%) and GNAI2 (24\%) were detected, with the majority occurring at known activating hotspots in key functional domains. Our in vitro data further suggested that targeted inhibition of these pathways may be useful in treatment of this disease.

In other PTCLs, gene expression profiling identified unique signatures for major histological subgroups, including angioimmunoblastic T-cell lymphoma (AITL), anaplastic lymphoma kinase (ALK)-positive and ALK-negative anaplastic large cell lymphoma, adult T-cell leukemia/lymphoma and NKTCL [42]. This classification allowed the identification of novel diagnostic and prognostic subtypes of PTCL, and provided biological rationale for novel therapeutic targets in this heterogeneous group of diseases. In a more recent study, we examined primary nodal NK/T-cell lymphoma-a clinically ambiguous entity currently included in the revised 2016 WHO lymphoma classification as an EBV-positive variant of PTCL, not otherwise specified [43]. Compared with extranodal NKTCL, this nodal phenotype was distinctively characterized by upregulation of PD-L1 and T-cell-related genes, downregulation of CD56, as well as loss of 14q11.2 which correlated with loss of TCR loci and T-cell origin.

\section{Conclusion and future perspectives}

In recent years, we have witnessed encouraging progress in lymphoma research across East Asia. The ALSG has taken on a key leadership role in attempting to advance clinically relevant research particularly on the more Asian-centric lymphoma subtypes such as NKTCL and MEITL. Nonetheless, to improve patient outcomes in these areas, sustained concerted efforts will be required to conduct translational science studies and clinical trials. Importantly, it is anticipated that the development of patient-derived xenograft models in mice will provide additional insights on Asian-centric lymphoma including NKTCL and MEITL [44]. Given that these tumors are rare, there thus arises an excellent opportunity 
for collaborative discovery and an international cooperative effort to devise novel therapeutic strategies against them.

Acknowledgements This work was supported by the National Medical Research Council of Singapore (TCR12DEC005), Tanoto Foundation Professorship in Medical Oncology, New Century Foundation Limited, Ling Foundation, Singapore National Cancer Centre Research Fund as well as the SingHealth Duke-NUS Academic Medical Centre and Oncology ACP.

\section{Compliance with ethical standards}

Conflict of interest The authors declare no conflict of interest.

\section{References}

1. Kwong YL, Anderson BO, Advani R, Kim WS, Levine AM, Lim ST, Asian Oncology Summit. Management of T-cell and naturalkiller-cell neoplasms in Asia: consensus statement from the Asian Oncology Summit 2009. Lancet Oncol. 2009;10(11):1093-101.

2. Tan D, Tan SY, Lim ST, Kim SJ, Kim WS, Advani R, Kwong YL. Management of B-cell non-Hodgkin lymphoma in Asia: resourcestratified guidelines. Lancet Oncol. 2013;14(12):e548-61.

3. Au WY, Weisenburger DD, Intragumtornchai T, Nakamura S, Kim WS, Sng I, Vose J, Armitage JO, Liang R, International Peripheral T-Cell Lymphoma Project. Clinical differences between nasal and extranasal natural killer/T-cell lymphoma: a study of 136 cases from the International Peripheral T-Cell Lymphoma Project. Blood. 2009;113(17):3931-7.

4. Kim SJ, Jung HA, Chuang SS, Hong H, Guo CC, Cao J, Hong XN, Suzuki R, Kang HJ, Won JH, Chng WJ, Kwong YL, Suh C, Song YQ, Zhu J, Tay K, Lim ST, Suzumiya J, Lin TY, Kim WS, Asia Lymphoma Study Group. Extranodal natural killer/T-cell lymphoma involving the gastrointestinal tract: analysis of clinical features and outcomes from the Asia Lymphoma Study Group. J Hematol Oncol. 2013;16(6):86.

5. Takata K, Hong ME, Sitthinamsuwan P, Loong F, Tan SY, Liau JY, Hsieh PP, Ng SB, Yang SF, Pongpruttipan T, Sukpanichnant S, Kwong YL, Hyeh Ko Y, Cho YT, Chng WJ, Matsushita T, Yoshino T, Chuang SS. Primary cutaneous NK/T-cell lymphoma, nasal type and CD56-positive peripheral T-cell lymphoma: a cellular lineage and clinicopathologic study of 60 patients from Asia. Am J Surg Pathol. 2015;39(1):1-12.

6. Yamaguchi M, Miyazaki K. Current treatment approaches for NK/T-cell lymphoma. J Clin Exp Hematop. 2017;57:98-108.

7. Tse E, Kwong YL. The diagnosis and management of NK/T-cell lymphomas. J Hematol Oncol. 2017;10(1):85

8. Yamaguchi M, Tobinai K, Oguchi M, Ishizuka N, Kobayashi Y, Isobe Y, Ishizawa K, Maseki N, Itoh K, Usui N, Wasada I, Kinoshita T, Ohshima K, Matsuno Y, Terauchi T, Nawano S, Ishikura S, Kagami Y, Hotta T, Oshimi K. Phase I/II study of concurrent chemoradiotherapy for localized nasal natural killer/T-cell lymphoma: Japan Clinical Oncology Group Study JCOG0211. J Clin Oncol. 2009;27(33):5594-600.

9. Yamaguchi M, Tobinai K, Oguchi M, Ishizuka N, Kobayashi Y, Isobe Y, Ishizawa K, Maseki N, Itoh K, Usui N, Wasada I, Kinoshita T, Hotta T, Tsukasaki K, Oshimi K. Concurrent chemoradiotherapy for localized nasal natural killer/T-cell lymphoma: an updated analysis of the Japan clinical oncology group study JCOG0211. J Clin Oncol. 2012;30(32):4044-6.

10. Kim SJ, Kim K, Kim BS, Kim CY, Suh C, Huh J, Lee SW, Kim JS, Cho J, Lee GW, Kang KM, Eom HS, Pyo HR, Ahn YC, Ko
YH, Kim WS. Phase II trial of concurrent radiation and weekly cisplatin followed by VIPD chemotherapy in newly diagnosed, stage IE to IIE, nasal, extranodal NK/T-Cell Lymphoma: Consortium for Improving Survival of Lymphoma study. J Clin Oncol. 2009;27(35):6027-32.

11. Yamaguchi M, Kwong YL, Kim WS, Maeda Y, Hashimoto C, Suh C, Izutsu K, Ishida F, Isobe Y, Sueoka E, Suzumiya J, Kodama T, Kimura H, Hyo R, Nakamura S, Oshimi K, Suzuki R. Phase II study of SMILE chemotherapy for newly diagnosed stage IV, relapsed, or refractory extranodal natural killer (NK)/ T-cell lymphoma, nasal type: the NK-Cell Tumor Study Group study. J Clin Oncol. 2011;29(33):4410-6.

12. Kwong YL, Kim WS, Lim ST, Kim SJ, Tang T, Tse E, Leung AY, Chim CS. SMILE for natural killer/T-cell lymphoma: analysis of safety and efficacy from the Asia Lymphoma Study Group. Blood. 2012;120(15):2973-80.

13. Kwong YL, Kim SJ, Tse E, Oh SY, Kwak JY, Eom HS, Do YR, Mun YC, Lee SR, Shin HJ, Suh C, Chuang SS, Lee YS, Lim ST, Izutsu K, Suzuki R, Relander T, d'Amore F, Schmitz N, Jaccard A, Kim WS. Sequential chemotherapy/radiotherapy was comparable with concurrent chemoradiotherapy for stage I/II NK/Tcell lymphoma. Ann Oncol. 2017. https://doi.org/10.1093/annon c/mdx684.

14. Suzuki R, Kwong Y, Maeda Y, Sakai R, Kim W, Suh C, Ishida F, Izutsu K, Isobe Y, Maeda T, Sueoka E, Okoshi Y, Takizawa J, Kobayashi H, Nakamura S, Suzumiya J, Oshimi K, Yamaguchi M. 5-year follow-up of the SMILE phase II study for newlydiagnosed stage IV, relapsed or refractory extranodal NK/T-cell lymphoma, nasal type. Hematol Oncol. 2015;33(S1):140.

15. Chan A, Tang T, Ng T, Shih V, Tay K, Tao M, Quek R, Lim ST. To SMILE or not: supportive care matters. J Clin Oncol. 2012;30(9):1015-6.

16. Hwang WY, Koh LP, Lim ST, Linn YC, Loh YS, Koh MB, Diong CP, Lee JJ, Zhang XH, Rajgor D, Gandhi M, Shah A, Goh YT. Multicenter study of comparative outcomes of hematopoietic stem cell transplant for peripheral T cell lymphoma and natural killer/T-cell lymphoma. Leuk Lymphoma. 2011;52(7):1382-6.

17. Tse E, Chan TS, Koh LP, Chng WJ, Kim WS, Tang T, Lim ST, Lie AK, Kwong YL. Allogeneic haematopoietic SCT for natural killer/T-cell lymphoma: a multicentre analysis from the Asia Lymphoma Study Group. Bone Marrow Transplant. 2014;49(7):902-6.

18. Yhim HY, Kim JS, Mun YC, Moon JH, Chae YS, Park Y, Jo JC, Kim SJ, Yoon DH, Cheong JW, Kwak JY, Lee JJ, Kim WS, Suh C, Yang DH. Consortium for improving survival of lymphoma study. Clinical outcomes and prognostic factors of up-front autologous stem cell transplantation in patients with extranodal natural killer/T cell lymphoma. Biol Blood Marrow Transplant. 2015;21(9):1597-604.

19. Kwong YL, Chan TSY, Tan D, Kim SJ, Poon LM, Mow B, Khong PL, Loong F, Au-Yeung R, Iqbal J, Phipps C, Tse E. PD1 blockade with pembrolizumab is highly effective in relapsed or refractory NK/T-cell lymphoma failing L-asparaginase. Blood. 2017;129(17):2437-42.

20. Farid M, Yau YW, Tay K, Quek R, Tao M, Koo GC, Loong S, Lim ST. A promising new regimen for the treatment of advanced extranodal NK/T cell lymphoma. Acta Oncol. 2011;50(4):589-90.

21. Ahn HK, Kim SJ, Hwang DW, Ko YH, Tang T, Lim ST, Kim WS. Gemcitabine alone and/or containing chemotherapy is efficient in refractory or relapsed NK/T-cell lymphoma. Investig New Drugs. 2013;31(2):469-72.

22. Chan JY. A clinical overview of centrosome amplification in human cancers. Int J Biol Sci. 2011;7(8):1122-44.

23. Venkatakrishnan K, Kim TM, Lin CC, Thye LS, Chng WJ, Ma B, Chen MH, Zhou X, Liu H, Kelly V, Kim WS. Phase 1 study of the investigational Aurora A kinase inhibitor alisertib (MLN8237) in 
East Asian cancer patients: pharmacokinetics and recommended phase 2 dose. Investig New Drugs. 2015;33(4):942-53.

24. Kim HK, Moon SM, Moon JH, Park JE, Byeon S, Kim WS. Complete remission in CD30-positive refractory extranodal NK/T-cell lymphoma with brentuximab vedotin. Blood Res. 2015;50(4):254-6.

25. Hari P, Raj RV, Olteanu H. Targeting CD38 in refractory extranodal natural killer cell-T-cell lymphoma. N Engl J Med. 2016;375(15):1501-2.

26. Lee J, Suh C, Park YH, Ko YH, Bang SM, Lee JH, Lee DH, Huh J, Oh SY, Kwon HC, Kim HJ, Lee SI, Kim JH, Park J, Oh SJ, Kim K, Jung C, Park K, Kim WS. Extranodal natural killer T-cell lymphoma, nasal-type: a prognostic model from a retrospective multicenter study. J Clin Oncol. 2006;24(4):612-8.

27. Yang Y, Zhang YJ, Zhu Y, Cao JZ, Yuan ZY, Xu LM, Wu JX, Wang W, Wu T, Lu B, Zhu SY, Qian LT, Zhang FQ, Hou XR, Liu QF, Li YX. Prognostic nomogram for overall survival in previously untreated patients with extranodal NK/T-cell lymphoma, nasal-type: a multicenter study. Leukemia. 2015;29(7):1571-7.

28. Kim SJ, Yoon DH, Jaccard A, Chng WJ, Lim ST, Hong H, Park Y, Chang KM, Maeda Y, Ishida F, Shin DY, Kim JS, Jeong SH, Yang DH, Jo JC, Lee GW, Choi CW, Lee WS, Chen TY, Kim K, Jung SH, Murayama T, Oki Y, Advani R, d'Amore F, Schmitz N, Suh C, Suzuki R, Kwong YL, Lin TY, Kim WS. A prognostic index for natural killer cell lymphoma after non-anthracycline-based treatment: a multicentre, retrospective analysis. Lancet Oncol. 2016;17(3):389-400.

29. Ito $Y$, Kimura H, Maeda $Y$, Hashimoto $C$, Ishida F, Izutsu $K$, Fukushima N, Isobe Y, Takizawa J, Hasegawa Y, Kobayashi H, Okamura S, Kobayashi H, Yamaguchi M, Suzumiya J, Hyo R, Nakamura S, Kawa K, Oshimi K, Suzuki R. Pretreatment EBVDNA copy number is predictive of response and toxicities to SMILE chemotherapy for extranodal NK/T-cell lymphoma, nasal type. Clin Cancer Res. 2012;18(15):4183-90.

30. Kim SJ, Choi JY, Hyun SH, Ki CS, Oh D, Ahn YC, Ko YH, Choi S, Jung SH, Khong PL, Tang T, Yan X, Lim ST, Kwong YL, Kim WS, Asia Lymphoma Study Group. Risk stratification on the basis of Deauville score on PET-CT and the presence of Epstein-Barr virus DNA after completion of primary treatment for extranodal natural killer/T-cell lymphoma, nasal type: a multicentre, retrospective analysis. Lancet Haematol. 2015;2(2):e66-74.

31. Schmitt C, Sako N, Bagot M, Huang Y, Gaulard P, Bensussan A. Extranodal NK/T-cell lymphoma: toward the identification of clinical molecular targets. J Biomed Biotechnol. 2011;2011:790871.

32. Li Z, Xia Y, Feng LN, Chen JR, Li HM, Cui J, Cai QQ, Sim KS, Nairismägi ML, Laurensia Y, Meah WY, Liu WS, Guo YM, Chen LZ, Feng QS, Pang CP, Chen LJ, Chew SH, Ebstein RP, Foo JN, Liu J, Ha J, Khoo LP, Chin ST, Zeng YX, Aung T, Chowbay B, Diong CP, Zhang F, Liu YH, Tang T, Tao M, Quek R, Mohamad F, Tan SY, Teh BT, Ng SB, Chng WJ, Ong CK, Okada Y, Raychaudhuri S, Lim ST, Tan W, Peng RJ, Khor CC, Bei JX. Genetic risk of extranodal natural killer T-cell lymphoma: a genome-wide association study. Lancet Oncol. 2016;17(9):1240-7.

33. Jiang L, Gu ZH, Yan ZX, Zhao X, Xie YY, Zhang ZG, Pan CM, Hu Y, Cai CP, Dong Y, Huang JY, Wang L, Shen Y, Meng G, Zhou JF, Hu JD, Wang JF, Liu YH, Yang LH, Zhang F, Wang JM, Wang Z, Peng ZG, Chen FY, Sun ZM, Ding H, Shi JM, Hou J, Yan JS, Shi JY, Xu L, Li Y, Lu J, Zheng Z, Xue W, Zhao WL, Chen Z, Chen SJ. Exome sequencing identifies somatic mutations of DDX3X in natural killer/T-cell lymphoma. Nat Genet. 2015;47(9):1061-6.

34. Koo GC, Tan SY, Tang T, Poon SL, Allen GE, Tan L, Chong SC, Ong WS, Tay K, Tao M, Quek R, Loong S, Yeoh KW, Yap
SP, Lee KA, Lim LC, Tan D, Goh C, Cutcutache I, Yu W, Ng CC, Rajasegaran V, Heng HL, Gan A, Ong CK, Rozen S, Tan P, Teh BT, Lim ST. Janus kinase 3-activating mutations identified in natural killer/T-cell lymphoma. Cancer Discov. 2012;2(7):591-7.

35. Lee S, Park HY, Kang SY, Kim SJ, Hwang J, Lee S, Kwak SH, Park KS, Yoo HY, Kim WS, Kim JI, Ko YH. Genetic alterations of JAK/STAT cascade and histone modification in extranodal NK/Tcell lymphoma nasal type. Oncotarget. 2015;6(19):17764-76.

36. Lim ST, Song T, Lim JQ, Laurensia Y, Pang WL, Nagarajan S, Wijaya GC, Tan J, Tang T, Nairismägi ML, Ong CK. Oncogenic activation of STAT3 pathway drives PD-L1 expression in natural killer/T cell lymphoma. J Clin Oncol. 2017;35(15 suppl):7549.

37. Tse E, Gill H, Loong F, Kim SJ, Ng SB, Tang T, Ko YH, Chng WJ, Lim ST, Kim WS, Kwong YL. Type II enteropathy-associated T-cell lymphoma: a multicenter analysis from the Asia Lymphoma Study Group. Am J Hematol. 2012;87(7):663-8.

38. Chan JK, Chan AC, Cheuk W, Wan SK, Lee WK, Lui YH, Chan WK. Type II enteropathy-associated T-cell lymphoma: a distinct aggressive lymphoma with frequent $\gamma \delta$ T-cell receptor expression. Am J Surg Pathol. 2011;35(10):1557-69.

39. Tan SY, Ooi AS, Ang MK, Koh M, Wong JC, Dykema K, Ngeow J, Loong S, Gatter K, Tan L, Lim LC, Furge K, Tao M, Lim ST, Loong F, Cheah PL, Teh BT. Nuclear expression of MATK is a novel marker of type II enteropathy-associated T-cell lymphoma. Leukemia. 2011;25(3):555-7.

40. Tan SY, Chuang SS, Tang T, Tan L, Ko YH, Chuah KL, Ng SB, Chng WJ, Gatter K, Loong F, Liu YH, Hosking P, Cheah PL, Teh BT, Tay K, Koh M, Lim ST. Type II EATL (epitheliotropic intestinal T-cell lymphoma): a neoplasm of intra-epithelial T-cells with predominant CD8 $\alpha \alpha$ phenotype. Leukemia. 2013;27(8):1688-96.

41. Nairismägi ML, Tan J, Lim JQ, Nagarajan S, Ng CC, Rajasegaran V, Huang D, Lim WK, Laurensia Y, Wijaya GC, Li ZM, Cutcutache I, Pang WL, Thangaraju S, Ha J, Khoo LP, Chin ST, Dey S, Poore G, Tan LH, Koh HK, Sabai K, Rao HL, Chuah KL, Ho YH, Ng SB, Chuang SS, Zhang F, Liu YH, Pongpruttipan T, Ko YH, Cheah PL, Karim N, Chng WJ, Tang T, Tao M, Tay K, Farid M, Quek R, Rozen SG, Tan P, Teh BT, Lim ST, Tan SY, Ong CK. JAK-STAT and G-protein-coupled receptor signaling pathways are frequently altered in epitheliotropic intestinal T-cell lymphoma. Leukemia. 2016;30(6):1311-9.

42. Iqbal J, Wright G, Wang C, Rosenwald A, Gascoyne RD, Weisenburger DD, Greiner TC, Smith L, Guo S, Wilcox RA, Teh BT, Lim ST, Tan SY, Rimsza LM, Jaffe ES, Campo E, Martinez A, Delabie J, Braziel RM, Cook JR, Tubbs RR, Ott G, Geissinger E, Gaulard P, Piccaluga PP, Pileri SA, Au WY, Nakamura S, Seto M, Berger F, de Leval L, Connors JM, Armitage J, Vose J, Chan WC, Staudt LM. Lymphoma Leukemia Molecular Profiling Project and the International Peripheral T-cell Lymphoma Project. Gene expression signatures delineate biological and prognostic subgroups in peripheral T-cell lymphoma. Blood. 2014;123(19):2915-23.

43. Ng SB, Chung TH, Kato S, Nakamura S, Takahashi E, Ko YH, Khoury JD, Yin CC, Soong R, Jeyasekharan AD, Hoppe MM, Selvarajan V, Tan SY, Lim ST, Ong CK, Nairismägi ML, Maheshwari P, Choo SN, Fan S, Lee CK, Chuang SS, Chng WJ. EBVassociated primary nodal T/NK-cell lymphoma shows distinct molecular signature and copy number changes. Haematologica. 2017. https://doi.org/10.3324/haematol.2017.180430.

44. Nairismägi ML, Pang WL, Huang D, Tan J, Lim JQ, Li ZM, Ha J, Laurensia Y, Wijaya GC, Ng CY, Santoso EG, Teh BT, Tan SY, Lim ST, Ong CK. Generation of non-Hodgkin lymphoma patient-derived xenografts and in depth characterization of a monomorphic epitheliotropic intestinal T-cell lymphoma model. Blood. 2016;128:4128. 